\title{
Synthesis and properties of elastomeric poly(propylene)
}

\author{
Stefan Mansel ${ }^{1}$, Ernesto Pérez ${ }^{* 1}$, Rosario Benavente $^{1}$, José M. Pereña $^{1}$, Antonio Bello ${ }^{1}$, Werner Röll ${ }^{2}$, \\ Robin Kirsten ${ }^{2}$,Stefan Beck ${ }^{2}$,Hans-Herbert Brintzinger ${ }^{2}$ \\ ${ }^{1}$ Instituto de Ciencia y Tecnología de Polímeros (CSIC), Juan de la Cierva 3, 28006 Madrid, Spain \\ ernestop@fresno.csic.es \\ ${ }^{2}$ Fakultät für Chemie, Universität Konstanz, Postfach 5560, 78434 Konstanz, Germany
}

\begin{abstract}
SUMMARY: Elastomeric poly(propylene) with low percentages of isotactic pentads and high molecular weight was synthesized using unbridged "oscillating" metallocenes. The polymer sample with the highest [mmmm] content (22\%) shows a small amount of crystallinity, which is highly influenced by the thermal history, and differs significantly in stress-strain and dynamic mechanical properties from all other samples. Polymers with lower isotacticity index, although lacking crystallinity in thermal analysis, differ in their viscoelastic behaviour from those of atactic poly(propylene). In dynamic mechanical analysis the $\gamma$ relaxation at low temperature shows high sensitivity to low isotactic contents.
\end{abstract}

\section{Introduction}

Elastomeric poly(propylene) is known since Natta isolated a stereoblock fraction from poly(propylene) prepared with a classical heterogeneous catalyst system ${ }^{1,2)}$. Subsequently improved catalysts have been made for tailoring this material, which contains blocks of crystallizable stereoregular sequences and stereorandom amorphous ones ${ }^{3)}$. The use of metallocene catalysts in the stereoselective propylene polymerization ${ }^{4}$ led to further developments for the preparation of elastomeric poly(propylene $)^{5,6)}$. Recently, Waymouth et al. ${ }^{7,8)}$ found that unbridged "oscillating" metallocenes such as bis(2-phenylindenyl ${ }_{2} \mathrm{ZrCl}_{2}$ ( $\mathbf{1}$ in Fig. 1 ), by rotation of the substituted indenyl ligand, lead to the formation of isoselective racemic and non-stereoselective meso stereoisomers of the metallocene during chain growth, which yields a highly stretchable atactic-isotactic stereoblock poly(propylene) with elastomeric properties.

In this work we analyze the thermal and viscoelastic behaviour of elastomeric poly(propylene) samples with very low percentages of isotactic pentads $(8 \%<[\mathrm{mmmm}]$ $<22 \%$ ) and high molecular weight. They were synthe-

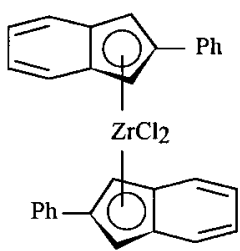

1

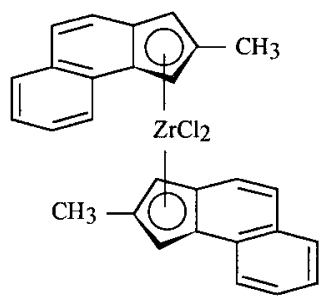

$2 \mathrm{a}$

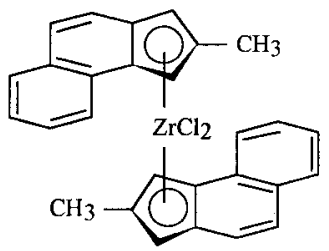

$2 \mathrm{~b}$

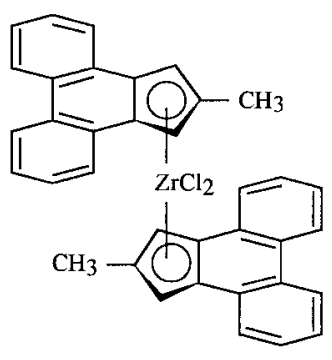

3

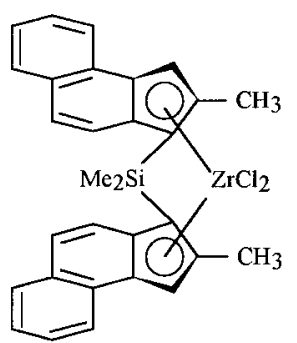

4

Fig. 1. Catalyst precursors 1-4 
Tab. 1. Experimental conditions and results of propylene polymerizations with the catalyst systems 1-4/MAO

\begin{tabular}{|c|c|c|c|c|c|}
\hline Polymer & P-22 & P-16 & P-15 & P-8 & P-6.25 \\
\hline Catalyst & 1 & $2 \mathbf{a}$ & $2 \mathbf{a}$ & 3 & 4 \\
\hline $\bar{M}_{\mathrm{w}}$ & 580000 & 823900 & 241500 & 802800 & 70500 \\
\hline $\bar{M}_{\mathrm{w}} / \bar{M}_{\mathrm{n}}$ & 2.07 & 2.21 & 1.67 & 2.52 & 1.77 \\
\hline$\%$ mmmm pentads & 22 & 16 & 15 & 8 & 6.25 \\
\hline$\frac{\text { Temperature }}{{ }^{\circ} \mathrm{C}}$ & 0 & 0 & 0 & 0 & 50 \\
\hline$\frac{\text { Propene pressure }}{\text { bar }}$ & 2 & 4 & 2 & 2 & 2 \\
\hline$\frac{\text { Reaction time }}{h}$ & 2 & 0.5 & 3 & 1 & 4 \\
\hline$\underline{\text { Yield }}$ & 9.7 & 26 & 27 & 10.2 & 5.5 \\
\hline$\frac{\text { Productivity }}{(\mathrm{kg} \mathrm{PP} /(\mathrm{mol}[\mathrm{Zr}] \cdot \mathrm{h}}$ & 388 & 2100 & 731 & 816 & 1700 \\
\hline
\end{tabular}

sized by using metallocene/methylaluminoxane (MAO) as catalysts where the unbridged ligand framework consists of bulky substituted indenyl derivatives in order to hinder the free rotation of the indenyl ligands (precursors 1-3). The bridged meso-precursor 4 was also used in propylene polymerization in order to get an ideal atactic poly(propylene) sample for a comparison study.

\section{Results and discussion}

\section{Synthesis of catalyst precursors and their application in the propylene polymerization catalysis}

The bis(2-phenylindenyl)zirconium dichloride complex $\mathbf{1}$ was prepared as described in the literature by Waymouth et al. ${ }^{7)}$ and was used as precursor in the MAO-activated propylene polymerization catalysis. To obtain a poly(propylene) (PP) sample with a significant amount of isotactic sequences the polymerization was performed at $0{ }^{\circ} \mathrm{C}$. The resulting polymer P-22 showed a high molecular weight and an isotacticity index of $22 \%[\mathrm{mmmm}]$. The synthesis of the metallocene complex bis(2-methylbenz[e]indenyl)zirconium dichloride 2 was recently published by Rausch et al. ${ }^{9)}$ By means of activation with MAO or triphenylcarbenium tetrakis(pentafluorophenyl)borate (trityl)/triisobutylaluminium the authors obtained atactic poly(propylene) at polymerization temperatures of $0^{\circ}$ and $25^{\circ} \mathrm{C}$. Following a similar procedure (see Experimental part) we observed the formation of rac-like $\mathbf{2 a}$ as well as meso-like $\mathbf{2} \mathbf{b}$ isomers. The isomers were separated by means of fractionated crystallization and the rac-like symmetry of $\mathbf{2 a}$ was determined by ${ }^{1} \mathrm{H}$ NMR. After methylation with methyllithium, only one signal for the $\mathrm{Zr}-\mathrm{CH}_{3}$ protons at $-0.81 \mathrm{ppm}$ was detectable. The same isomer composition was already obtained when bis(2methylbenz[e]indenyl)diethoxysilane was treated with 2 equivalents of potassium hydride and $\mathrm{ZrCl}_{4}(\mathrm{thf})_{2}$ in tetrahydrofuran (THF), whereby the diethoxysilane bridge is lost ${ }^{10)}$. For the propylene polymerization, a 93:7 rac-like/ meso-like isomer mixture was used. At $0{ }^{\circ} \mathrm{C}$ propylene was polymerized with $\mathbf{2} \mathbf{a} / \mathrm{MAO}$ at monomer pressures of 2 and 4 bar, respectively. As expected, poly(propylene) sample P-15, formed at 2 bar propylene pressure, showed a lower molecular weight and reduced productivity than sample P-16, obtained at 4 bar. A somewhat higher isotacticity index of $16 \%$ [ $\mathrm{mmmm}$ ] for P-16 compared with $15 \%$ [ $\mathrm{mmmm}$ ] for P-15 does correspond to the proposed oscillating stereocontrol model, which predicts a higher isotacticity at higher monomer concentration ${ }^{7,8)}$. The synthesis of bis(2-methylcyclopenta[1]phenanthren) $\mathrm{ZrCl}_{2}$ 3 and meso- $\mathrm{Me}_{2} \mathrm{Si}$ (2-methylbenz[e]indenyl) ${ }_{2} \mathrm{ZrCl}_{2} 4$ and their applications in MAO-activated propylene polymerizations already has been reported ${ }^{11,12)}$. While 3/MAO resulted in a poly(propylene) with $8 \%[\mathrm{mmmm}]^{11)}$, an ideal atactic polymer with $6.25 \%$ [ $\mathrm{mmmm}]$ was produced by meso-4/MAO ${ }^{12)}$.

Tab. 1 shows conditions and results of the different polymerization experiments. In Fig. 2 the normalized methyl pentad distributions of polymers P-22, P-16, and P-8 are shown. The mmmm pentad content of the prepared polymers varies from 8 up to $22 \%$, whereas the mmmr content does not change significantly, having a value of approximately $14 \%$. Consequently, the average length of isotactic sequences, $n_{\text {iso }}$, which can be calculated according to the formula $n_{\text {iso }}=4+2$ ([mmmm $] /$ $[m m m r])^{13)}$, increases with increasing isotactic content. Thus, for the three polymers in Fig. 2 it takes the values of $7.1,6.0$, and 5.2, respectively.

\section{Thermal and viscoelastic behaviour}

The differential scanning calorimetry (DSC) heating curves of the different samples are presented in Fig. 3. It is observed that P-22 is the only one that shows an appreciable melting peak, with a maximum at $144^{\circ} \mathrm{C}$, and with a total enthalpy of melting of $2.5 \mathrm{~J} \cdot \mathrm{g}^{-1}$. However, the 


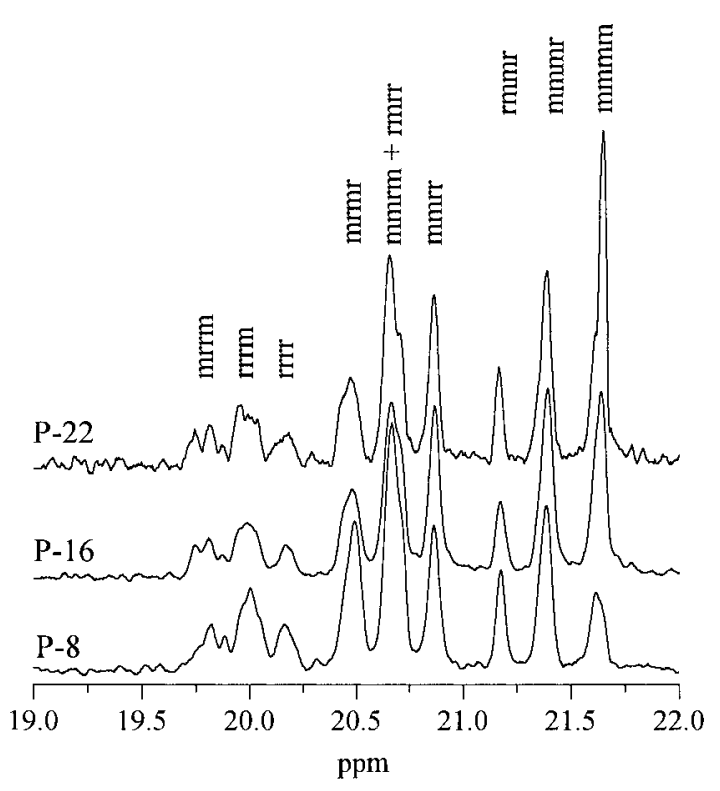

Fig. 2. Methyl pentad distributions for samples P-22, P-16, and P-8 $\left({ }^{13} \mathrm{C}\right.$ NMR)

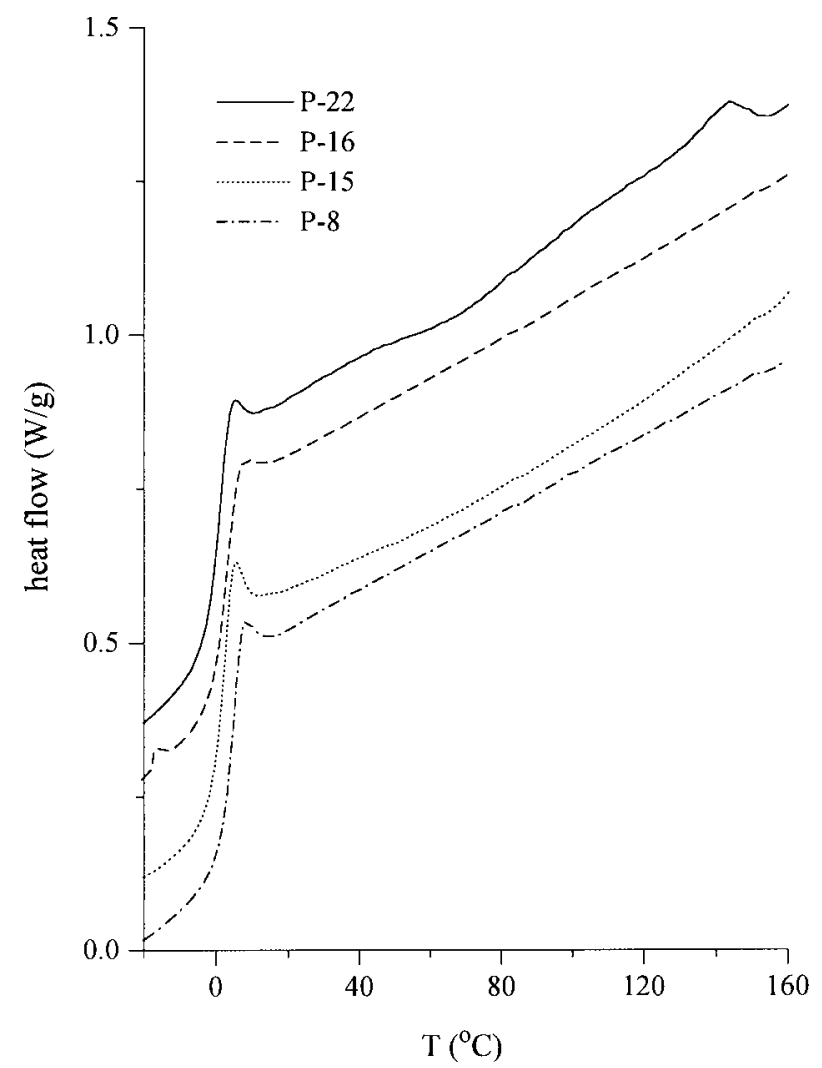

Fig. 3. DSC heating curves $\left(40^{\circ} \mathrm{C} / \mathrm{min}\right)$ of the different samples (second melting)

cooling of this sample from the melt, like those of all other samples, did not show any crystallization peak. In fact, it can be observed in Fig. 3 that the second melting of sample P-22 showed, after the glass transition, a cold crystallization at about $67^{\circ} \mathrm{C}$, i.e., this sample crystallizes on heating.

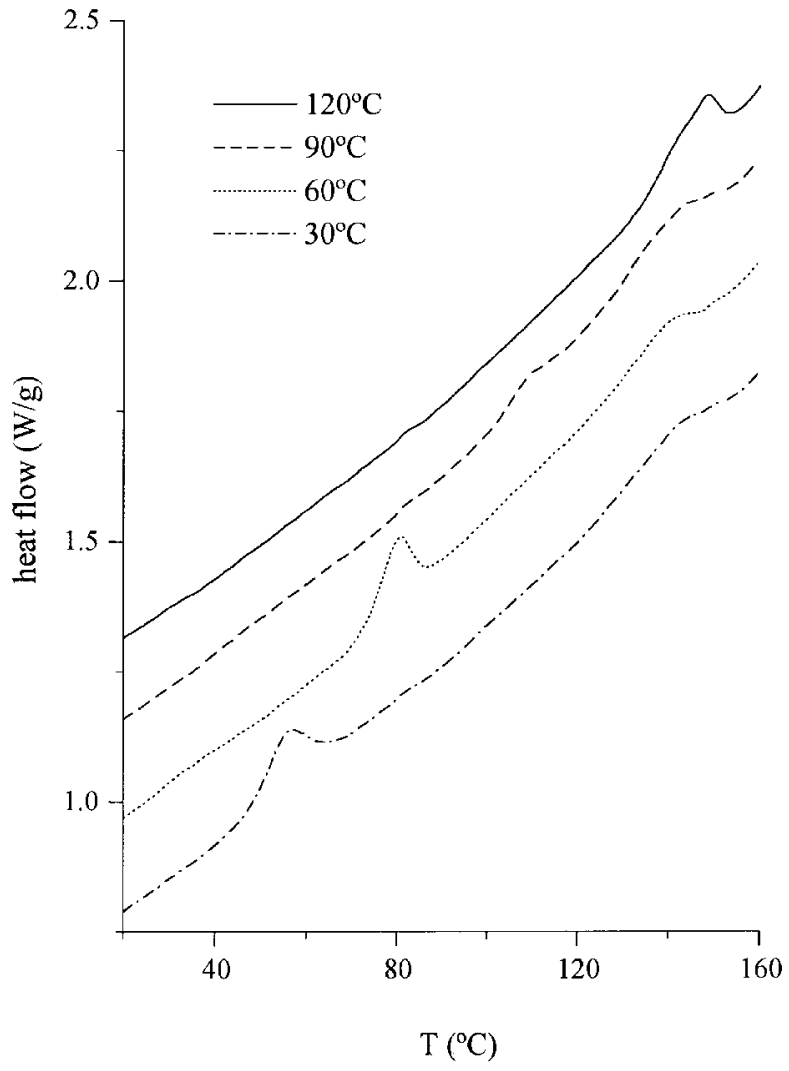

Fig. 4. DSC heating curves of sample P-22 after annealing for $200 \mathrm{~min}$ at different temperatures

Moreover, crystallization in sample P-22 can be also attained by annealing at temperatures above the glass transition during long times. This annealing leads to other melting endotherm at about $20-30^{\circ} \mathrm{C}$ above the annealing temperature (Fig. 4). This endotherm is assigned to the melting of crystalline entities which show small size and/or low degree of perfection. Evidently, the sample left at room temperature experiences these annealing effects and after several days a melting peak at $54^{\circ} \mathrm{C}$ is obtained, with an enthalpy of melting, $\Delta H_{\mathrm{m}}$, of $6 \mathrm{~J} \cdot \mathrm{g}^{-1}$.

Samples P-16, P-15, and P-8, however, behaved at any thermal history like the amorphous, ideal atactic poly(propylene) P-6.25, i.e., no melting peak was detected. Therefore, and considering the values of $n_{\text {iso }}$ mentioned above, it seems that this parameter has to reach a value of at least 7 to obtain crystalline domains. This limiting value is approximately the same as that reported recently for elastomeric poly(propylene)s synthesized with unsymmetrical zirconocene catalysts ${ }^{6}$.

The samples showed a glass transition temperature, $T_{\mathrm{g}}$, between 0 and $5^{\circ} \mathrm{C}$. No clear influence of isotactic or crystalline content on the value of $T_{\mathrm{g}}$ was observed.

Wide-angle X-ray scattering experiments also provide evidence for a small amount of crystallinity only in sample P-22. Subtraction of diffractogram P-16 from that of sample $\mathbf{P - 2 2}$ yielded the characteristic values of $2 \theta$ for 


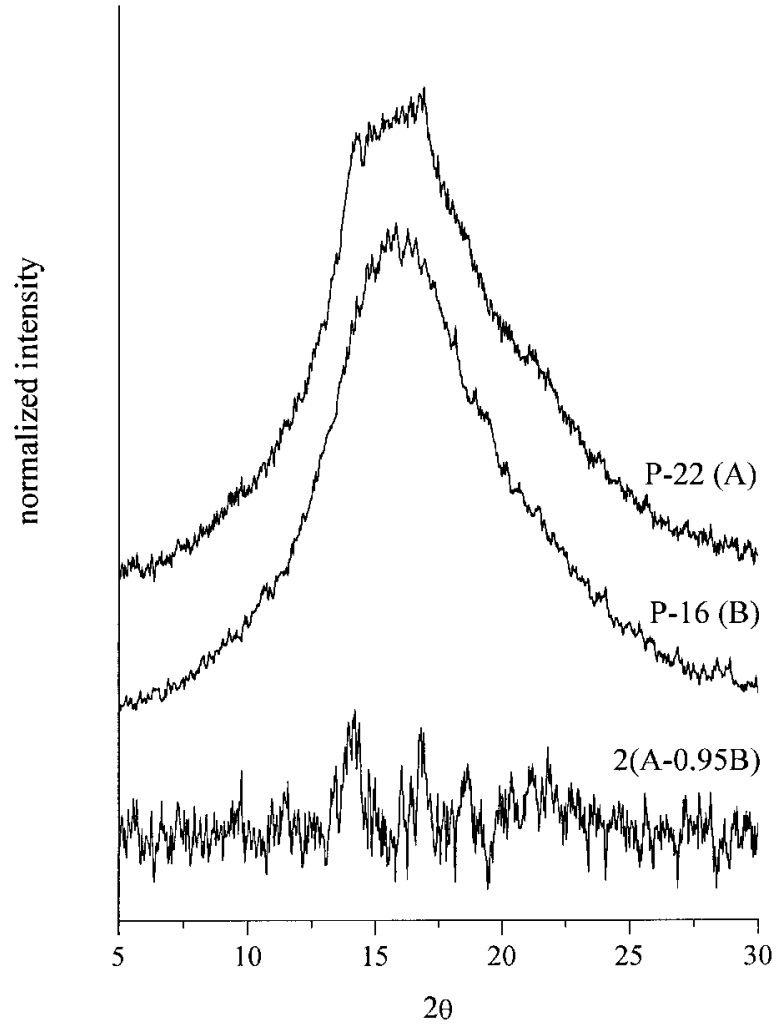

Fig. 5. X-ray diffractograms for samples P-22 (A) and P-16 (B), after a long time at room temperature, and a subtraction of both diffractograms

the $\alpha$-modification of crystalline isotactic poly(propylene) at about 14.1, 16.8, 18.7, and 21.2-21.8 degree $^{14)}$ (Fig. 5).

In stress-strain tests the buildup of stress is measured as the specimen is being deformed at a constant rate. Since all the elastomers considered here show very high molecular weights, the polymer molecules become entangled enough to show a true rubber behaviour. Fig. 6 demonstrates the influence of isotacticity and crystallinity. The increase in modulus and simultaneous decrease in elongation to break in sample $\mathbf{P - 2 2}$ is mainly produced due to the presence of a small amount of crystalline phase which affects some polymer properties, acting as a physical crosslinking. For the other samples, a small initial increase in modulus was observed when increasing the molecular weight or the isotactic content, although their isotactic segments are too short to detect the formation of crystalline domains. Their elongation to break becomes of the order of more than $3500 \%$. This unusually high elongation is the result of the rubbery phase being a continuous phase. Nevertheless all polymers showed elastomeric properties: after 100 and $300 \%$ elongation the elastic recovery value was always more than 85 .

Dynamical mechanical tests showed in all samples one clear maximum for $\tan \delta$ at temperatures between 10 and $15^{\circ} \mathrm{C}$, which is slightly higher than the temperature of the

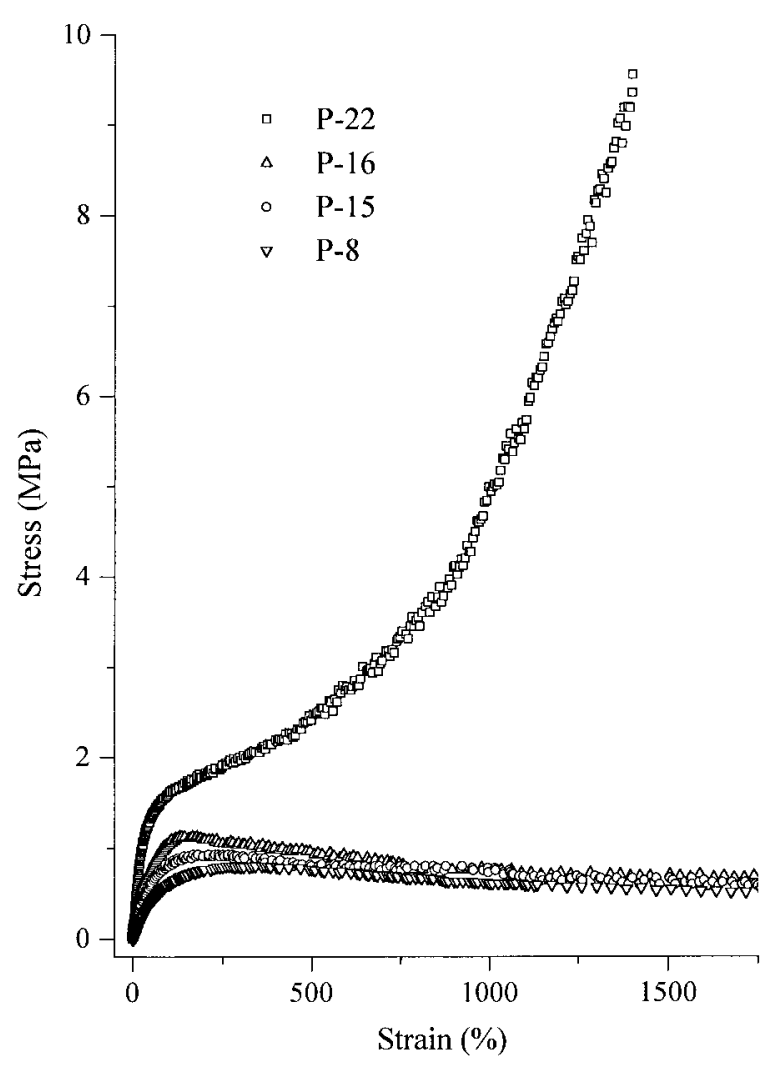

Fig. 6. Stress-strain behaviour of different samples after a long time at room temperature

DSC glass transition, as usual. The $\tan \delta$ is a damping term and is a measure of the ratio of heat energy dissipated to the maximum energy in the material during one cycle of oscillation. For sample P-22 the intensity decreased significantly to the value of 1.2 , owing to the appearance of a crystalline content, while all other samples exhibit values around 1.8. Consequently, the transition must be due to relaxations in amorphous chain segments. A second broad and weak transition could be detected between $-120^{\circ} \mathrm{C}$ and $T_{\mathrm{g}}$. This transition is known as the $\gamma$ transition $^{15)}$ and, as can be seen in Fig. 7, it showed a high sensitivity to small amounts of isotactic contents in the specimens, independently of whether they show crystallinity or not.

\section{Conclusions}

The origin of different thermal and mechanical behaviour in low isotactic elastomeric poly(propylene) mainly lies in the presence of isotactic sequences with an average length large enough to form crystalline domains. In amorphous poly(propylene) a small content of short isotactic sequences can increase the molecular interactions, which influences the dynamic mechanical and mechanical properties. 


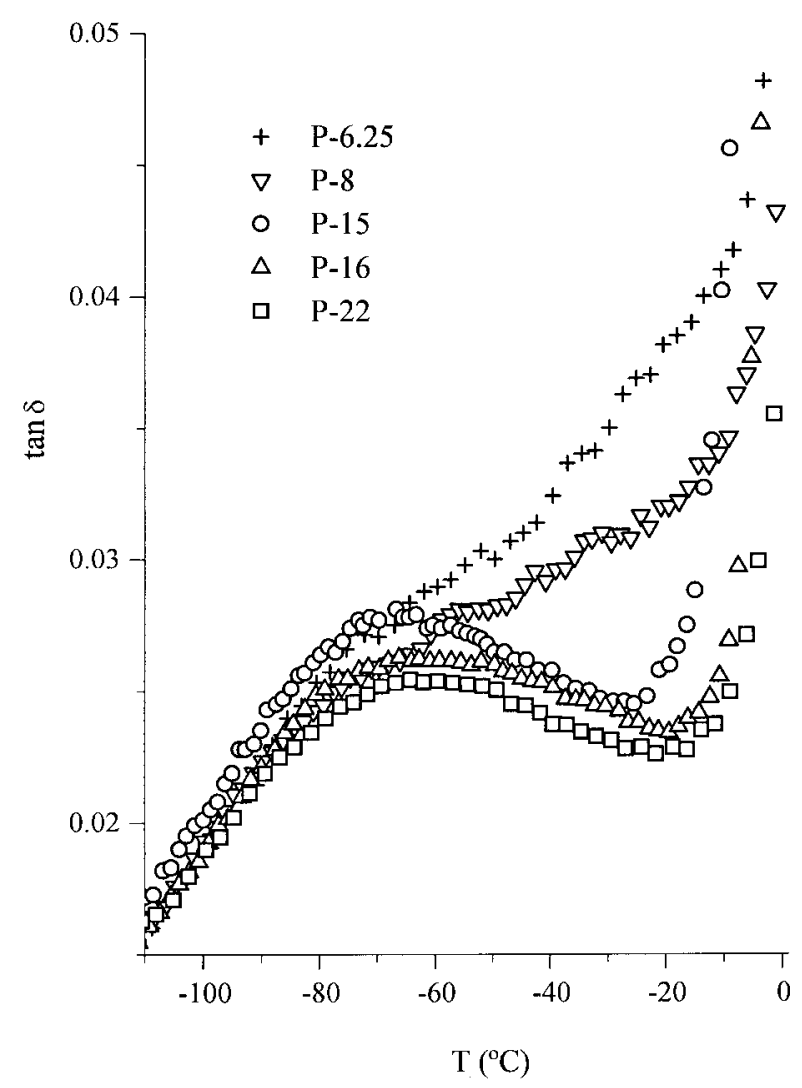

Fig. 7. Temperature dependence of loss tangent $\delta$ (at $30 \mathrm{~Hz}$ ) for the different samples after a long time at room temperature

\section{Experimental part}

\section{Preparation of bis $\left(\eta^{5}\right.$-2-methylbenz[e]indenyl)zirconium dichloride 2}

To a solution of 2-methylbenz[e]indene $(8.84 \mathrm{~g}, 49 \mathrm{mmol})$ in diethyl ether $(100 \mathrm{ml})$ and hexane $(100 \mathrm{ml}), 1.6 \mathrm{M}$ butyllithium $(30.6 \mathrm{ml}, 49 \mathrm{mmol})$ were added at $-78^{\circ} \mathrm{C}$. The reaction mixture was warmed to ambient temperature and the solid residue was washed with pentane $(5 \times 50 \mathrm{ml})$ and dried in vacuo. The dilithium salt was suspended in $150 \mathrm{ml}$ toluene and stirred with $\mathrm{ZrCl}_{4}(5.7 \mathrm{~g}, 24 \mathrm{mmol})$ for $2 \mathrm{~d}$ at room temperature. The yellow suspension was dried in vacuo and extracted with dichloromethane. Concentration of the solvent gave $2(5.5 \mathrm{~g}, 10.56 \mathrm{mmol})$ in $44 \%$ yield with rac-like $\mathbf{2 a}$ : meso-like $\mathbf{2} \mathbf{b}=1.25: 1$. Fractionated crystallization from dichloromethane at $-30^{\circ} \mathrm{C}$ gave $\mathbf{2 a}(2.3 \mathrm{~g}, 4.4 \mathrm{mmol})$.

${ }^{1} \mathrm{H}$ NMR for $2 \mathbf{a}\left(600 \mathrm{MHz}, \mathrm{C}_{6} \mathrm{D}_{6}\right): \delta=7.87\left(\mathrm{~m}, 2 \mathrm{H}, \mathrm{H}^{6}\right)$, $7.53\left(\mathrm{~m}, 2 \mathrm{H}, \mathrm{H}^{9}\right), 7.36\left(\mathrm{~m}, 2 \mathrm{H}, \mathrm{H}^{7}\right), 7.28\left(\mathrm{~m}, 2 \mathrm{H}, \mathrm{H}^{8}\right), 7.17$ $\left(\mathrm{m}, 2 \mathrm{H}, \mathrm{H}^{5}\right), 6.93\left(\mathrm{~m}, 2 \mathrm{H}, \mathrm{H}^{4}\right), 6.50\left(\mathrm{~m}, 2 \mathrm{H}, \mathrm{H}^{3}\right), 5.59(\mathrm{~d}$, $\left.2 \mathrm{H}, \mathrm{H}^{1}\right), 1.74$ (s, 6H, 2-Me).

${ }^{13} \mathrm{C}$ NMR for $2 \mathbf{a}\left(600 \mathrm{MHz}, \mathrm{C}_{6} \mathrm{D}_{6}\right): \delta=129.29\left(\mathrm{~s}, 2 \mathrm{C}, \mathrm{C}^{9}\right)$, $127.56\left(\mathrm{~s}, 2 \mathrm{C}, \mathrm{C}^{7}\right), 127.17\left(\mathrm{~s}, 2 \mathrm{C}, \mathrm{C}^{5}\right), 126.82\left(\mathrm{~s}, 2 \mathrm{C}, \mathrm{C}^{8}\right)$, $124.87\left(\mathrm{~s}, 2 \mathrm{C}, \mathrm{C}^{6}\right), 122.08\left(\mathrm{~s}, 2 \mathrm{C}, \mathrm{C}^{4}\right), 108.93\left(\mathrm{~s}, 2 \mathrm{C}, \mathrm{C}^{3}\right)$, 107.23 (s, 2C, $\mathrm{C}^{1}$ ), 16.32 (s, 2C, 2-Me).

${ }^{1} \mathrm{H}$ NMR for $2 \mathbf{b}\left(600 \mathrm{MHz}, \mathrm{C}_{6} \mathrm{H}_{6}\right): \delta=7.80\left(\mathrm{~m}, 2 \mathrm{H}, \mathrm{H}^{6}\right)$, $7.53\left(\mathrm{~m}, 2 \mathrm{H}, \mathrm{H}^{9}\right), 7.36\left(\mathrm{~m}, 2 \mathrm{H}, \mathrm{H}^{7}\right), 7.28\left(\mathrm{~m}, 2 \mathrm{H}, \mathrm{H}^{8}\right), 7.18$ $\left(\mathrm{m}, 2 \mathrm{H}, \mathrm{H}^{5}\right), 7.14\left(\mathrm{~m}, 2 \mathrm{H}, \mathrm{H}^{4}\right), 6.36\left(\mathrm{~m}, 2 \mathrm{H}, \mathrm{H}^{3}\right), 5.74(\mathrm{~d}$, $\left.2 \mathrm{H}, \mathrm{H}^{1}\right), 1.70$ (s, 6 H, 2-Me).

${ }^{13} \mathrm{C}$ NMR for $2 \mathbf{b}\left(600 \mathrm{MHz}, \mathrm{C}_{6} \mathrm{D}_{6}\right): \delta=129.29\left(\mathrm{~s}, 2 \mathrm{C}, \mathrm{C}^{9}\right)$, $127.56\left(\mathrm{~s}, 2 \mathrm{C}, \mathrm{C}^{7}\right), 127.05\left(\mathrm{~s}, 2 \mathrm{C}, \mathrm{C}^{5}\right), 126.83\left(\mathrm{~s}, 2 \mathrm{C}, \mathrm{C}^{8}\right)$, 124.70 (s, 2C, $\left.\mathrm{C}^{6}\right), 122.18$ (s, 2C, $\left.\mathrm{C}^{4}\right), 109.21$ (s, 2C, $\mathrm{C}^{1}$ ), 106.28 (s, 2C, $\left.\mathrm{C}^{3}\right), 16.23$ (s, 2C, 2-Me).

\section{Polymerization procedures}

Polymerizations were conducted in a 11 autoclave (previously cleaned with a 0.5 mol- $\%$ solution of $\mathrm{Al}(\mathrm{i}-\mathrm{butyl})_{3}$ in toluene and dried in vacuo) filled with $350 \mathrm{ml}$ of purified toluene, using a solution of $6.15 \mu \mathrm{mol}$ of precursor $1-3$, or $0.4 \mu \mathrm{mol}$ of $\mathbf{4}$, followed by the addition of $0.45 \mathrm{~g}$ of methylaluminoxane (Witco AG, molecular weight ca. 900) in toluene at the corresponding temperature and a constant propylene pressure. After the appropriate reaction time, the reaction mixture was drained from the autoclave and stirred into a mixture of 11 methanol and $10 \mathrm{ml}$ concentrated aqueous HCl. Polymers P-22, P-16, P-15, and P-8 precipitated as polymer cakes and were kept for $2 \mathrm{~d}$ in $\mathrm{MeOH}$ and dried for one day at $60^{\circ} \mathrm{C}$ to constant weight. Polymer P-6.25 was received by removal of the solvent of the toluene/MeOH soluble phase and was also dried to constant weight.

\section{Polymer characterization}

Molecular weight distributions were determined by gel permeation chromatography (Kunststoff-Labor, BASF AG). Polymer ${ }^{13} \mathrm{C}$ NMR spectra were measured in $\mathrm{C}_{2} \mathrm{D}_{2} \mathrm{Cl}_{4}$ at $120^{\circ} \mathrm{C}$ on a $250 \mathrm{MHz}$ NMR spectrometer operated at $62.9 \mathrm{MHz}$ and analyzed with respect to the pentad distributions. Thermal properties were measured by means of a Perkin Elmer DSC-7 calorimeter, interfaced to a data station and connected to a cooling system. The weight of the samples ranged from 6 to $9 \mathrm{mg}$. Due to the very small enthalpy of melting involved, a heating rate of $40^{\circ} \mathrm{C} / \mathrm{min}$ was used. $\mathrm{X}$-ray diffraction patterns were obtained at room temperature with a Geiger counter X-ray diffractometer from Philips, employing nickel-filtered $\mathrm{Cu} K \alpha$ radiation. Dumb-bell specimens, cut from sheets around $0.5 \mathrm{~mm}$ thick by using a standardized die $(15 \mathrm{~mm}$ long and $1.9 \mathrm{~mm}$ wide in the narrow section), were uniaxially drawn at room temperature in an Instron dynamometer (model 4301) with a maximum load cell of $100 \mathrm{~N}$ and a deformation rate of $1 \mathrm{~cm} / \mathrm{min}$. Dynamic mechanical measurements were carried out with a Polymer Laboratories Mk II Dynamic Mechanical Thermal Analyzer working in the tensile mode, in a dry nitrogen atmosphere, at a heating rate of $1.5^{\circ} \mathrm{C} / \mathrm{min}$. The specimens used were rectangular strips $2.2 \mathrm{~mm}$ wide with length and thickness around 14 and $0.3 \mathrm{~mm}$, respectively.

Acknowledgement: The financial support of the $E U$ (Networks ERBCHRXCT-930158 and ERB4061PL970898) and of the Comisión Interministerial de Ciencia y Tecnología (project MAT96-2310) is gratefully acknowledged. 
1) G. Natta, G. Mazzanti, G. Crespi, G. Moraglio, Chim. Ind. (Milan) 39, 275 (1957)

2) G. Natta, J. Polym. Sci. 34, 531 (1959)

3) J. W. Collette, D. W. Ovenall, W. H. Buck, R. C. Ferguson, Macromolecules 22, 3858 (1989)

4) H. H. Brintzinger, D. Fischer, R. Mülhaupt, B. Rieger, R. Waymouth, Angew. Chem. 107, 1255 (1995); Angew. Chem., Int. Ed. Engl. 34, 1143 (1995)

5) D. T. Mallin, M. D. Rausch, Y. G. Lin, S. Dong, J. C. W. Chien, J. Am. Chem. Soc. 112, 2030 (1990)

6) A. M. Bravakis, L. E. Bailey, M. Pigeon, S. Collins, Macromolecules 31, 1000 (1998)

7) G. W. Coats, R. M. Waymouth, Science 267, 217 (1995)
8) E. Hauptmann, R. M. Waymouth, J. Am. Chem. Soc. 117, 11586 (1995)

9) P. Foster, J. C. W. Chien, M. D. Rausch, Organometallics 15, 4951 (1996)

10) W. Röll, unpublished results, University of Konstanz (1997)

11) N. Schneider, PhD thesis, University of Konstanz (1997)

12) U. Stehling, $P h D$ thesis, University of Konstanz (1995)

13) W. J. Gauthier, S. Collins, Macromolecules 28, 3779 (1995)

14) A. Turner Jones, J. M. Aizlewood, D. R. Beckett, Makromol. Chem. 75, 134 (1964)

15) “Anelastic and Dielectric Effects in Polymeric Solids", N. G. McCrum, B. E. Read, G. Williams, Eds., Dover Publications, Inc., New York, 1991, p. 377 